\title{
Sporting Chance: Indigenous Participation \\ in Australian Sport History
}

\author{
Sean Gorman \\ Curtin University, Western Australia
}

\begin{abstract}
For many non-Indigenous Australians the only time they have any engagement with Indigenous peoples, history or issues is through watching sport on television or being at a football match at ground like the MCG. This general myopia and indifference by settler Australians with Indigenous Australians manifests itself in many ways, but perhaps most obscenely in the simple fact that Indigenous Australians die nearly 20 years younger than the rest of Australia's citizens. Many non-Indigenous Australians do not know this. Sport in many ways has offered Indigenous Australians a platform from which to begin the slow, hard process for social justice and equity to be actualised. This paper will discuss the participation of Indigenous Australians in sport and show how it has enabled Indigenous Australians to create a space so that they can speak out against the injustices they have experienced and to improve race relations going into the future. The central contention is that through sport all Australians can begin a process of engaging with Indigenous history as a means to improve race relations between the two groups.
\end{abstract}

Sport has been our greatest ally (Michael Long 19/5/2009).

\section{Background}

History has shown us that many relationships, friendships or unions between first Australians and settlers has been fraught with danger, and in many cases doomed. Consider, for example, the ramifications of the 1905 Aborigines Act in Western Australia. Anna Haebich notes that this legislation was originally designed out of the concerns of the Chief Protector of Aborigines, Mr Henry Charles Prinsep, who sought to "make provision for the better protection and care of the Aboriginal inhabitants of Western Australia” (Haebich 1988, p.83). Prinsep was "particularly concerned at the growing number of Aboriginal Children of mixed decent growing up in 'native camps'. In his opinion, they learned only 'laziness and vice' and left to their own devices they would grow up to be 'vagrants and outcast' and 'not only a disgrace but a menace to society”” (Haebich 1988, p. 57). Officially, the 1905 Act promoted education, medical and housing concerns as specific provisions for Indigenous Western Australians. As Haebich has argued, however, in reality this legislation 
laid the basis for the development of repressive and coercive state control over the state's Aboriginal population ... [the] Act drove a wedge between them and the wider community and served to hamper efforts [for them] to make their own way of life. (Haebich 1988, p. 83).

This type of paternalism has led directly to Aboriginal disempowerment and remains a grave concern in contemporary Australia where nearly all of the socio-economic indicators as provided by the Australian Bureau of Statistics show that to be born an Indigenous Australian means one enters a life of hardship, economic uncertainty, disease and early death. As basic health, welfare, housing and education are the inalienable rights of all Australian citizens it is Indigenous Australians who are suffering third world experiences and being left behind in the modern Australia.

In this paper I would like to summarise some of the historical moments whereby Indigenous Australians have overcome great injustice, adversity and hardship to play elite sport in Australia. In doing so I consider the incredibly important role that sport has played in Australian history to show how some Indigenous Australians have struggled against great adversity to achieve success. In doing so my aim is to argue the case for a wider appreciation of the role of sport in Aboriginal lives. It is through Indigenous sporting narratives one can begin to reconsider other areas where Indigenous people have enriched and contributed to Australian society.

For me the 'light-bulb’ moment came when I was interviewing renowned Australian Football League (AFL) and Essendon past player Michael Long for a research project. His quote, which appears at the top of this paper 'Sport has been our greatest ally' drove home to me that without sport perhaps the predicament for Indigenous peoples' welfare and wellbeing might indeed be worse than it currently is. This, for me, is a powerful statement, because Long himself had to stand firm amongst great public criticism, some of which came from Essendon Football club itself, to enable better conditions in the AFL, not just for Indigenous Australians but for all. He reflects:

It was a very hard thing to do because I didn't have all the answers or solutions and I didn't get support until later on. For some of the other players I reckon it was a hard thing because they'd be asking 'what's he going on about?' (Long 19/5/2009).

In many respects the Indigenous struggle on the football field is the one that many Aboriginal and Torres Strait Islander Australians experience in the everyday, and so the struggle of Indigenous Australian athletes could be characterised as long and arduous, but one that has 
had very real consequences for enabling understanding and change (Tatz in Headon 2001; Tatz \& Tatz 2000). The struggle could be epitomised by the indelible image of Nicky Winmar and his silent, dignified reply to the hostile Collingwood crowd in 1993 (Klugman \& Osmond 2009). Or Michael Long's stand when he was vilified in the first ANZAC day game that eventually ushered in the Racial and Religious Vilification laws (Rule 30). In 1995, this enabled Australia, as a nation, to look at racism at the individual and societal level through the prism of sport (Gardiner 1997; Warren \& Tsaousis 1997). But there have also been less notable struggles. For example, back in the 1920s, Doug (later Sir Douglas) Nicholls was refused a jumper at Carlton as it was claimed his 'smell' was intolerable to players and trainers alike. Then there is the fact Jim Krakouer was suspended for a total of 25 games, over a season's worth, due to retaliating against the racialised verbal and physical attention that was shown to him and his younger brother Phil (Gorman 2005). Further, during their playing careers West Coast Eagles players Chris Lewis and teammate Troy Ugle received anonymous death threats and hate mail. The vitriol was so disturbing that the West Coast Eagles sought counselling in order to help these players cope (Wilson 25/8/1991, p. 6).

The struggle, in many respects, has come down to what the colour of one's skin has represented, as the history of Indigenous and non-Indigenous relations has a long and difficult past; it is a past that we are still grappling with today. As Colin Tatz explains, this is a matter of history and our perceptions of it:

The phrase from 'plantation to playing field' expresses the history of black American sport...Aboriginal history has been the reverse. They went from relative freedom, albeit in an era of genocide, to the isolated and segregated settlements and missions which were created to save them (Tatz \& Tatz 2000, p. 8).

At AFL matches across the country today, huge electronic screens broadcast a warning to all patrons that racial vilification at the ground will not be tolerated and will result in a substantial fine and ejection from the arena. However, it does not seem that long ago when Indigenous players were able to be abused for the colour of their skin. Since 1990, when the Victorian Football League (VFL) became the national Australian Football League (AFL), the game has had many challenges, but racial vilification presented itself differently to the myriad financial and administrative issues that the new, expanded national competition 
faced. The reason for this is that vilification was seen as an intrinsic part of the game that was used in the psychological struggle with one’s opponent. For the AFL Rule 30 states:

no person subject to these Rules shall act towards or speak to any other person in a manner, or engage in any other conduct which threatens, disparages, vilifies or insults another on the basis of that person's race, religion, colour, descent or national or ethnic origin (AFL, p.1).

With the introduction of Rule 30 in 1995 many said the game was going 'soft'. In a number of the interviews that I did for the book Brotherboys, Michael Long was seen by some nonIndigenous people as nothing more than a trouble maker, a 'jumped up' darkie who did not know his place. For many of the elder statesmen of the game, the ethos was 'what was said on the field stayed on the field.' It was used simply to get an edge over Indigenous opponents. If Aboriginal players could not take it they were 'weak'. This notion today is preposterous as racist behaviour has no place in sport or the broader society.

To try and get some measure on what this means one should try and imagine what the sporting landscape would be in Australia if Indigenous Australians did not play Australian football. Not that they did not exist; rather, that they did not play football in the same way that Indigenous participation in international cricket is virtually non-existent. ${ }^{1}$ Because of Australian football and Indigenous Australians' love of for it Indigenous participation in football has become a highly celebrated aspect of the Australian game. It is because of players like Nicky Winmar, Barry Cable, Michael Long, Chris Lewis, Byron Pickett, Polly Farmer and the Krakouer brothers that football is a space where one can investigate both positive and negative historical issues regarding race relations in Australia. In this way football ceases to be just a game but becomes a teacher, and through its lessons we may become, as Australians, a better team.

\section{Sport, History and Politics}

For many Indigenous Australians, sport, history and politics have become intertwined due to issues concerning wider societal struggles and the oppression of Aboriginal people. Many Indigenous athletes have had to adapt to politics and policy in order to survive, as financial

\footnotetext{
${ }^{1}$ Jason Gillespie is the only male Test cricketer to have played for Australia who identifies as being Indigenous - Kaurna from South Australia.
} 
and social self-determination were not accessible. Both Haebich and Tatz have shown that in the late 1800s and early to mid 1900s, rations, curfews and reserve life created massive everyday hardship and poverty. For Tatz, those who displayed ability in sport were able to supplement their seasonal incomes and rations with semi-professional foot races or boxing matches to survive. Hence these people were able to become more socially mobile and gain some begrudging acceptance in the broader community, which then afforded them some degree of status (bearing in mind that most Indigenous Australians prior to the 1967 referendum came under various state and territory acts which made many of them feel like native fauna). As Tatz suggests, this does not just focus on one historical period but many:

The lives of Aboriginal sportspersons, at any period of Australian history, help illustrate the discriminations faced by all Aborigines living at that period. (Tatz \& Tatz 2000, p. 9).

This rich historical vein of sport, race and history, is not adequately appreciated by many non-Indigenous Australians, which is surprising given the status in which sport is held in Australia. This is in contrast to Americans, many of whom are quite aware of African Americans (like baseballer Jackie Robinson) and their valuable social and historical input to the desegregation of baseball, basketball and American football, and the rise to prominence of African Americans in these sports (Lapchick 2008).

In this way sport enables us to see the many over-lapping themes of sport, politics, race and history. Tatz, for example, looks at key incidents, such as Cathy Freeman cloaking herself in the Aboriginal flag at the 1994 Commonwealth Games. This created a furore in the Australian media as many commentators claimed that Freeman should have refrained, because Aboriginal Australia is not recognised as a sovereign nation. However, as Tatz responded, “Those who deplored her “un-Australian” behaviour have no understanding of Aboriginal history” (Tatz in Headon 2001, p. 554). What he meant is that media commentators equally failed to acknowledge that no Indigenous Australian has ever formally signed an agreement that they have 'given up' their land to anyone. To put this another way, the Mabo decision in 1992 proves in law that Indigenous peoples and societies were established in Australia before 1788, and thus the notion of Terra Nullius is a fraud. For many non-Indigenous Australians this is a concept that they do not or cannot acknowledge, 
and so indifference becomes the way of handling that (un)reality. As Syd Jackson opined in an interview I had with him in 2008:

I know a lot of my Aboriginal brothers and sisters became isolated, lonely and discriminated against because they had no attachment and lived lonely lives... I think the challenge we face is trying to get to the top level of work and acceptance because general society don't want to see them (Indigenous Australians). (Jackson, 25 Sept, 2008, my emphasis).

In terms of overt racism, discrimination has not just come from opponents requiring an “edge” but from the sporting institutions themselves. As previously mentioned, Doug Nichols, Fitzroy Football Club’s champion and later Governor of South Australia, was declined a guernsey at Carlton in the 1920 because it was thought he smelt. In other words, he smelt because it was an accepted 'truth' amongst non-Indigenous Australians that Aboriginals were dirty and chose to live in squalid conditions. For many 'Blackfellas', they had no choice in these matters as the local tip or sewerage depot were the only places they were allowed to live (Haebich 1988). Other examples of this type of treatment include cricketer Eddie Gilbert and tennis ace Evonne Goolagong.

Eddie Gilbert, a devastatingly fast bowler and one of the few to bowl Bradman for a duck, spent his last years in a Brisbane sanatorium because of the "great mental concern” that racism had caused him during his time playing cricket, and being institutionalised in places like Cherbourg (Colman \& Edwards 2002, p.144). Gilbert was on many occasions made to take his meals away from the team whilst on tour with the Queensland state side. Some of Gilbert's team mates even refused to shake his hand after he had taken a wicket. Furthermore, Gilbert was unfairly branded a “chucker," the worst possible accusation for a bowler, costing him greater acceptance and recognition within cricketing circles.

Evonne Goolagong, perhaps the most internationally famous Indigenous sportsperson in Australia before Cathy Freeman, also experienced racism. During the 1980 Wimbeldon tournament a senior Victorian politician at the time said he hoped she “wouldn’t go walkabout like some old boong” (Tatz \& Tatz 2000, p. 29). It seems incredible by today’s standards that such a thing would ever be uttered and hopefully measures to penalise vilification within sport can help break down these attitudes elsewhere. 


\section{Football and History}

For many years it has been believed that the first Indigenous player was Joe Johnson, a 55 game defender who played in Fitzroy’s 1904-05 premiership team in the VFL. However, this assumption has proven to be incorrect as Albert 'Pompey' Austin played for Geelong in 1872, debuting against Carlton after arriving from Framlingham mission (Ruddell 2008). In many ways it was not just Austin or Johnson who can be seen as the Indigenous pioneers of the game. The reason why this is suggested is that since the 1930s the game has only seen a few Indigenous players in the VFL in each era: Doug Nicholls (Fitzroy: 1932-37), Norm McDonald (Essendon: 1947-53), Polly Farmer (Geelong: 1962-67) and Syd Jackson (Carlton: 1969-1976). In a sense, then, these players were all pioneers as they each created a space so that others might follow. Today this sees cohorts of Indigenous players on all AFL lists. These numbers are increasing every year.

It was not, however, until the early 1980s that the VFL/AFL saw an influx of Indigenous players with the arrival of the Krakouers to North Melbourne and Maurice Rioli at Richmond, which added to the playing stocks of Phil Egan (Richmond), Robbie Muir (St Kilda) and Kevin Taylor (South Melbourne). More significantly it was not until the advent of the West Coast Eagles in 1987 with the likes of Phil Narkle, Wally Matera and Chris Lewis did the 'racial' complexion of the AFL really start to change. With this also came stereotypical media reportage concerning 'Black Magic' and the explaining away of Indigenous players' 'skills' as 'natural' without due recognition of the hours of training and application that they had endured. This attention brought with it more supporter hostility and culminated in the famous round four fixture between St Kilda and Collingwood in 1993, when Nicky Winmar raised his jumper, thereby revealing his black skin, to a hostile Collingwood football crowd. At the time Winmar could not have conceived what the outcome of his action would have been. The Collingwood President Allan McAlister said at the time that Winmar and team mate Gilbert McAdam would be respected "as long as they conducted themselves like white people on and off the field” (Tatz, 2001, p.557). For the broader community it began the process of sparking great debate about racism in football and society. The reason that Winmar's stance has transcended the realm of sport and football and the fact that we are still talking about it is the power of its message: "You cannot ignore me anymore”, it silently screams. 
Then in 1995 came the Michael Long incident when Collingwood ruckman Damian Monkhorst, who was being tackled by Long, implored that "someone should get this black c..t off me”. Long refused to let the media spotlight on this incident drop, and he pursued the AFL on its lack of racism protocols, which eventually led to the introduction of the AFL's racial and religious vilification laws: Rule 30. Now, because of Long, all who play the game are protected from racial and religious abuse and the players undergo diversity education and cultural awareness programs as part of being a professional sportsperson. Indigenous participation in the AFL in 2010 for both rookie and senior lists is just on 11\%. Rule 30 could then be seen as a very important initiative not only for Aboriginal players but also for those players from minority backgrounds, like the Irish and African players, but also such Islamic AFL footballers like Bhachar Houli at Essendon. Can one imagine for a moment what the status of Houli's welfare would have been given the anti-Muslim sentiment following the terrorists attacks in a Australia post 9-11 ${ }^{2}$ It has taken these and other problematic moments concerned with racism in the AFL to reconsider the way we think about race and ethnicity in Australia and how it relates to sport and society more broadly. Yet this could only be done if one viewed not just the game differently but also the space on which it was played. With increased sponsorships and professionalism, the MCG ceased to simply be an oval where sport was played and, with the introduction of Rule 30, it became a workplace. In this way vilification was seen differently because one is looking at it through a different prism.

A hint that Australian society is perhaps slowly coming to understand the issue of racism more holistically was witnessed in 2005 when the popular commentator Rex Hunt referred to Collingwood’s Indigenous player Leon Davis playing ability as being “as black as a dog”. Hunt made frequent use of slang and colloquialisms, but this was beyond the pale - as he recognised by apologising on air immediately after he had vilified Davis. "I stopped in my tracks because I knew” Hunt conceded (Hogan 19/7/2005). However, the counterargument to this occurred only recently when ex Richmond player and father to current day Hawthorn player Campbell Brown, Mal Brown, jokingly described past Indigenous players as 'cannibals', sparking a furore in the media (Gorman 18/6/2010).

\footnotetext{
${ }^{2}$ Bachar Houli is a player for the Essendon Bombers and a devout practicing Muslim who has a prayer mat at the Essendon Football club so that he may undertake his prayers at certain times of the day.
} 
One of the biggest challenges that the AFL currently faces is how they will deal with the projected influx of Indigenous players into the game, especially those that come from remote areas like Austin Wonemaerri, Liam Jurrah and Ross Tungatalum. ${ }^{3}$ In the next 5 to 10 years it is expected that Indigenous players will make up between 20 and 25 percent of all player lists. There will be many positive outcomes from this if that happens. Specifically, the AFL will become the single biggest corporate employer of Indigenous people per capita in Australia. However, for people like Koori elder and president of Rumbalara in Shepparton, Paul Briggs, it is felt that the AFL needs to do more: “I still don't think the system is strong enough to handle [certain] cases. There needs to be a far more professional approach and strong case management of what these boys need. Once they take their footy jumper off and put their street clothes on its just too hard for them” (Wilson Sport 17/11/2007, p. 1).

Many would say that the solution for Indigenous footballers to succeed beyond the playing field is simple. Stay off alcohol and drugs, get an education and work hard. But there also needs to be some work done by the broader society to ensure that when young Indigenous footballers fall by the wayside we don't just point to the colour of their skin and suggest racial logic as the cause of failure. To put this simply: to understand an Indigenous footballer one needs to understand where they have come from, not just geographically but socially, historically, economically, politically and culturally. To fail to acknowledge these primary aspects is to fundamentally miss the point of Indigenous peoples' experiences in Australian history. Perhaps also we need to ask ourselves some other very simple questions. Why are there no Indigenous commentators, coaches, administrators, team managers, umpires or journalists working within mainstream AFL circles? Where are they? As Che Cockatoo Collins ruminated,

I ask the question, where are those coaches? Where are those board members? Where are those commissioners? And as much stick as the NRL had been given over the last few years, I mean, they've actually got a commissioner, an Aboriginal commissioner, Gordon Tallis, and how come we [the AFL] don't? And by putting people in roles like that, I think you change the landscape. (Cockatoo-Collins, 15/9/2009).

\section{Conclusion}

\footnotetext{
${ }^{3}$ All these players are from remote areas of Australia and have strong traditional backgrounds. For example English for Liam Jurrah is his fourth language.
} 
The steps that the AFL has taken to stamp out racism in football are something that should be commended by all members of the community. What has followed on from 1995 and the introduction of Rule 30 is also something that the AFL and the broader football public should recognise as a celebration, but also a recognition that something needed to change. Since then there has been a range of other positive outcomes for Indigenous people in the AFL and the broader community. For example, Indigenous sporting achievement and culture is recognised in games like 'Dreamtime at the G'. The AFL also has the Sportsready program, which helps to identify and develop job skills and pathways for Indigenous footballers during and after their careers. Qantas is in partnership with the AFL funding the KickStart program directed towards Indigenous youth between the ages of 5-15, promoting healthy lifestyles and physical activity. In the broader community, the Clontarf Foundation in Western Australia, the brain-child of former AFL coach Gerard Neesham, is a proactive franchise that combines football and education to take 'at risk' Indigenous youth and turn their lives around. Similarly, Rumbalara in Shepparton has participated in both the Goulburn Valley and Murray football leagues since 1997, and has fostered many education and social initiatives to engender greater involvement between the local Koori and town community.

On a personal level, working in this field for nearly 20 years has enabled me to sit down and talk with some of Australian football's most famous Indigenous players. What I have come to understand is that we should all be grateful that football is part of our lives as it enables us to see how far as a community we have come. As Tatz says:

Sport is a mirror of many things. It reflects political, social, economic and legal systems. It also reflects the Aboriginal experience... There has been much adversity including the genocidal impulses of settler society, physical isolation, legal separation, removal of children, social segregation and racial discrimination in all of its forms...For Aborigines and Islanders, there has been exclusion from competition, discrimination within it, and at times gross inequality of chances, choices and facilities (Tatz \& Tatz 2000, p. 7).

Football and our appreciation of it can and does assist in developing a greater awareness about the spectrum of people who come to the game and the contributions they can make. In some small way we can watch television or go to a football game on any weekend during winter and we can come to a greater appreciation of what football means to Indigenous and non-Indigenous Australians alike. This then can lead to greater engagements and 
appreciations on other levels and the spirit of coexistence in Australia can take root. In a postApology Australia, and in a country that loves its sport, this seems a fitting path to take.

\section{References}

Australian Football League. One Game For all Australians: How Australian Football has acted to counteract racial and religious abuse. Retrieved October 10, 2008, from www.afl.com.au/Portals/0/afl_docs/afl_hq/Policies/RacialReligious_lr.pdf

Cockatoo-Collins, C. 2009, 'Force for good: how Indigenous Australians have enriched football.' National Museum of Australia. Canberra. Retrieved January 18, 2010. From http://www.nma.gov.au/audio/transcripts/NMA_force_for_good_20090915.html

Colman, M., \& Edwards, K. 2002), Eddie Gilbert: The True Story of an Aboriginal Cricketing Legend, ABC Books, Sydney.

Gardiner, G. 1997, Football and Racism: The AFL's Racial and Religious Vilification Rule, Discussion Paper, No.6. Koori Reserch Centre, Monash University, Melbourne.

Gorman, S. 2010, “Ignorance lies at the heart of 'innocent' racist gibes.” Retrieved June 30, 2010 from http://www.theage.com.au/opinion/society-and-culture/ignorance-lies-at-the-heart-ofinnocent-racist-gibes-20100617-yjpv.html

Gorman, S. 2005, Brotherboys: The Story of Jim and Phillip Krakouer, Allen \& Unwin, Melbourne.

Haebich, A. 1988, For their own Good. Aborigines and Government in the South West of Western Australia 1900-1940, Nedlands University of Western Australia Press.

Hogan, J. 2005, “Hunt Apologises for Racial ‘Stuff up’.” Retrieved 22 July, 2005 Age. From http://www.theage.com.au/articles/2005/07/19/1121538946296.html

Jackson, S. 2008, Personal Interview Melbourne, 25/9/2008.

Klugman, M., \& Osmond. G. 2009, 'That Picture - Nicky Winmar and the history of an image'. Australian Aboriginal Studies. No. 2, pp. 80 - 91.

Lapchick. R. 2008, 100 Pioneers: African-Americans Who Broke Color Barriers in Sport, Fitness Information Technology.

Long, M. 2009, Personal Interview Melbourne, 19/5/2009.

Ruddell, T. 2008, 'Albert "Pompey" Austin: The first Aborigine to play senior football', in Peter Burke and June Senyard (eds), Behind the Play: Football in Australia, Maribyrnong Press, Melbourne.

Tatz, C. 1995, Obstacle Race: Aborigines in Sport, University of NSW Press, Sydney.

Tatz, C. 2001, “The Dark Side of Australian Sport”. In D. Headon (Ed.), The Best Ever Australian Sports Writing: A 200 year collection, Black Inc, Melbourne.

Tatz, C., \& Tatz, P. 2000, Black Gold: The Aboriginal and Islander Sports Hall of Fame, Aboriginal Studies Press, Canberra.

Warren, I., \& Tsaousis 1997, 'Racism and the law in Australian Rules Football: A critical analysis', Sporting Traditions vol.14, no. 1, pp. 27-53.

Wilson, C. 2007, The Age Sport, 17 November, p. 1.

Wilson, C. 1991, 'Racism on the field - AFL football's shameful secret', The Sunday Age 25 August p. 6. 